\title{
THE PROGNOSTIC VALUE OF BACTERICIDAL/PERMEABILITY-INCREASING PROTEIN IN INFANTS WITH CONGENITAL PATHOLOGY OF THE GASTROINTESTINAL TRACT
}

\author{
Minaev S. V., Isaeva A. V., Tovkan E.A., Gudiev Ch. G., Timofeev S. I., \\ Kachanov A. V., Romaneeva N. M.
}

\section{Stavropol State Medical University, Russian Federation}

\section{T} he problem of developing purulent-septic complications after neonatal surgery remains unsolved [1]. Many researchers believe the development of such complications affects the mortality in the given group of patients [2].

Despite the lack of common approaches to the early diagnosis and treatment of septic complications, some authors believe the mechanism of development is closely connected with the violation of cell membrane permeability and the subsequent translocation of intestinal flora through the intestinal membrane [3, 4]. This is also favored by the age characteristics of the newborn with immaturity of the immune and barrier systems.

In recent years, interest has increased in antimicrobial peptides (AMPs) and bactericidal/ permeability increasing protein (BPI) in particular, which is localized in the vacuoles of granulocytes [5]. Its concentration in serum increases in inflammatory diseases and allergic reactions. There are studies confirming its role in the destruction of bacterial cell membrane polysaccharides in vitro and in animal experiments. A high concentration of peptide in the blood is required to achieve a bactericidal effect [6]. A literature review revealed no publications considering this peptide as a marker of intestinal wall damage in neonates.

The aim of this study was to investigate the influence of bactericidal protein (BPI) on the development of complications after abdominal surgery in infants with congenital anomalies of the gastrointestinal tract.

Minaev Sergey, Professor, MD, PhD, Head of Department of Pediatric Surgery, Stavropol State Medical University; tel.: 79624507653; e-mail: sminaev@yandex.ru

Isaeva Alesya, MD, Assistant of Professor Department of Pediatric Surgery, Stavropol State Medical University; e-mail: isaeva_alesya@mail.ru

Tovkan Elena, MD, Assistant of Professor Department of Pediatrics, Stavropol State Medical University; e-mail: el.tovkan@yandex.ru

Gudiev Chersy, Postgraduate student of Pediatric Surgery Department of Pediatric Surgery, Stavropol State Medical University; e-mail: chersi05@mail.ru

Timofeev Sergey, Postgraduate student of Pediatric Surgery Department of Pediatric Surgery, Stavropol State Medical University; e-mail: timofeev_si@mail.ru
Material and Methods. This was a prospective non-randomized controlled study that included 24 infants who were treated in the intensive care unit of Children's Regional Clinical Hospital from 2010 to 2011. The inclusion criteria were as follows: 1) the presence of congenital anomalies of the gastrointestinal tract (GIT) that were diagnosed prenatally and 2) a surgical procedure in the first days after the diagnosis of surgical disease. The control points in the study were the number and type of septic complications and duration of mechanical ventilation. The exclusion criteria were multiple congenital anomalies and the child's death during the first day after surgery.

All of the children belonged to a group at high risk for postoperative septic complications, and at least one of the following factors was present: 1 ) the late arrival of newborns on the stage of specialized care, 2) transportation failure to comply with the standards by non-specialized vehicles, 3) longterm (over $15 \mathrm{~min}$ ) hypothermia.

The children were divided into two groups. Group $1(n=10)$ included newborns with inflammatory complications after surgery, and group $2(n=14)$ included children who had no complications after surgery. The control group consisted of healthy newborns $(n=20)$ after a normal physiological birth. The structure of the GIT congenital anomalies is presented in Table. All of the children underwent surgical correction of the congenital anomaly on the first or second day after diagnosis. Patients in both groups at all stages of care received complex intensive care in compliance with generally accepted principles of treatment in neonatology, pediatric surgery and anesthesiology and intensive care.

Characteristics of surgical pathology in newborns

\begin{tabular}{|l|c|c|c|r|}
\hline \multirow{2}{*}{ Diagnosis } & \multicolumn{2}{c|}{$\begin{array}{c}\text { Group 1 } \\
(\mathrm{n}=10)\end{array}$} & \multicolumn{2}{c|}{$\begin{array}{c}\text { Group 2 } \\
(\mathrm{n}=14)\end{array}$} \\
\cline { 2 - 5 } & $\mathrm{n}$ & $\%$ & $\mathrm{n}$ & $\%$ \\
\hline $\begin{array}{l}\text { Congenital duodenal } \\
\text { obstruction }\end{array}$ & 4 & 40 & 6 & 42.8 \\
\hline Jejuno-ileal atresia & 4 & 40 & 4 & 28.6 \\
\hline Hirschsprung's disease & 2 & 20 & 4 & 28.6 \\
\hline Total: & 10 & 100 & 14 & 100 \\
\hline
\end{tabular}


The vital signs of all the children were monitored via ECG monitoring of systolic, diastolic and mean arterial pressure by non-invasive method and tissue oxygen saturation $\left(\mathrm{SaO}_{2}\right)$. The hematocrit was controlled before and after the injection of solutions. The following blood parameters were determined: total protein, electrolytes ( $\mathrm{Na}, \mathrm{Ca}, \mathrm{K})$, sugar, creatinine, urea and liver enzymes (ALT, AST, alkaline phosphatase). The blood plasma BPI level was determined in the children preoperatively and on the $1^{\text {st }}, 3^{\text {rd }}, 7^{\text {th }}$ and $14^{\text {th }}$ postoperative days. The level of $\mathrm{BPI}$ «BCM Diagnostics» was determined using an ELISA.

The analysis of the reliability of the differences between the groups was carried out by methods of variation statistics using the licensed computer program Statistica 6.0. The data were reviewed using the Shapiro-Wilk method to choose an adequate method of statistical analysis. This result $(p=0.36)$ suggests the need for nonparametric statistical methods. We used the Wilcoxon test to analyze the statistical reliability between the groups. The critical significance level $(p)$ for verification of the statistical hypotheses in this study was set at 0.05 . The median (Me) interquartile range was $25-75 \%$.

Results. In group 1, the post-operative complications included anastomotic obstruction $(n=2)$, leakage at the anastomosis and prolonged adynamic ileus $(n=3)$, and sepsis or pneumonia $(n=5)$.

The level of BPI in group 1 was 3.33 (2.74-4.51) $\mathrm{ng} / \mathrm{ml}$ preoperatively and $4.49(1.48-5.7) \mathrm{ng} / \mathrm{ml}$ on the first postoperative day. After 3 days, the BPI level increased markedly to $15.75(3.32-50.5) \mathrm{ng} /$ $\mathrm{ml}$ and then decreased gradually on day 7 to 4.425 $(3.38-55.4) \mathrm{ng} / \mathrm{ml}$ and to $3.23(0.01-30.9) \mathrm{ng} / \mathrm{ml}$ 14 days after the operation (Fig. 1).

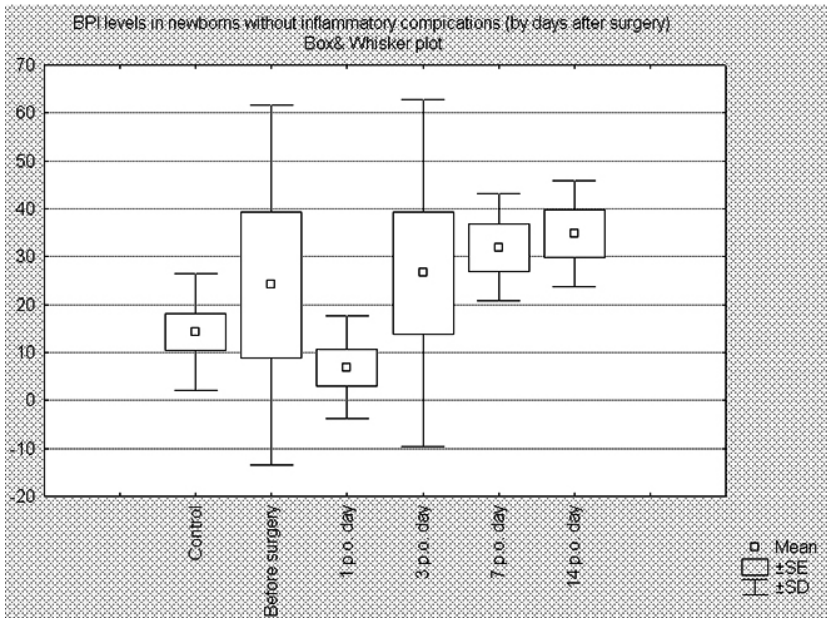

Fig. 1. BPI dynamics in infants with inflammatory complications

In group 2, the BPI level was 10.5 (3.35-19.05) $\mathrm{ng} / \mathrm{ml}$ preoperatively. On the 1 st postoperative day, it decreased to $2.755(1.835-6.545) \mathrm{ng} / \mathrm{ml}$, and on postoperative day 3 , the level remained stable at $2.915(1.37-55.5) \mathrm{ng} / \mathrm{ml}$. The BPI level increased on the $7^{\text {th }}$ postoperative day to 33.45 $(21.7-45.2) \mathrm{ng} / \mathrm{ml}$ and remained unchanged by the $14^{\text {th }}$ postoperative day at $34.5(34.5-34.5)$ $\mathrm{ng} / \mathrm{ml}$ (Fig. 2).

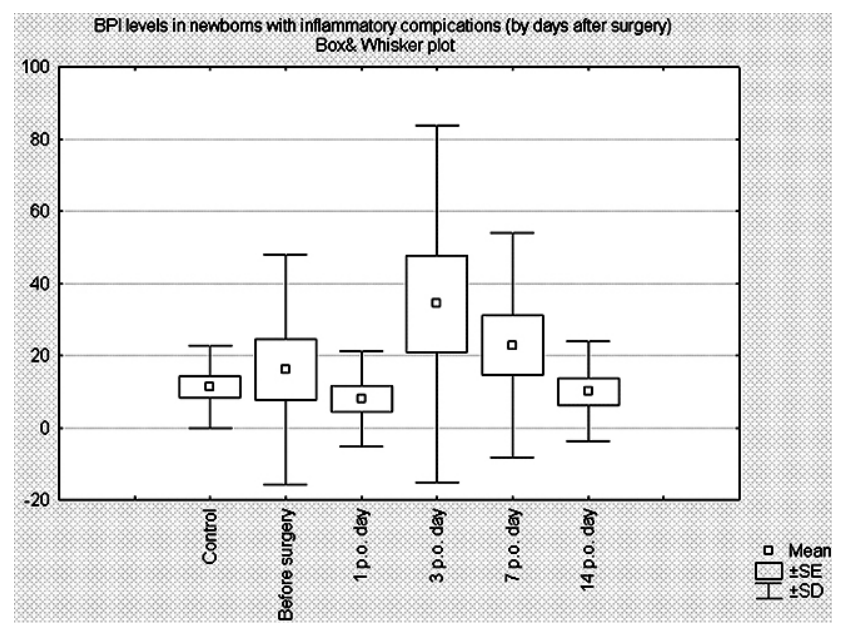

Fig. 2. BPI dynamics in newborns without inflammatory complications

When comparing the baseline BPI level, which increases the permeability of the cells in the treatment groups, using the Wilcoxon test, significant differences were detected $(p>0.05)$. Significant differences $(p>0.05)$ were detected between the serum BPI level in the serum of children in group 1 and group 2. There was a statistically significant $(p<0.05)$ increase in the serum BPI level in group 1 on the 3rd postoperative day. The level of bactericidal protein was significantly higher on the 1 st postoperative day $(p<0.05)$ in group 2 .

Discussion. The production of AMPs is commonly considered a primitive mechanism of immunity. The antimicrobial activity of saliva largely depends on histidine-rich AMPs known as histatins. Many more AMPs and AMP-like proteins exist and exhibit various functions apart from their antimicrobial properties. The AMP-like protein of the neutrophil granule content, bactericidal/permeability increasing protein $(\mathrm{BPI})$, is able to permeabilize bacterial membranes and function as an opsonin [7]. BPI stored in azurophil granules is a major constituent of neutrophils $(0.5$ to $1 \%$ of total protein) and is present in eosinophils in smaller amounts. The epithelial cells of the oral, gastrointestinal and female genital tracts produce BPI [8].

The potent and selective antibiotic and endotoxin-neutralizing properties of $\mathrm{BPI}$ manifest with $\mathrm{nM}$ concentrations of either the full-length BPI molecule or rBPI21 stimulated extensive preclinical and clinical testing of $\mathrm{rBPI} 21$. In a variety of animal models, recombinant human BPI (rBPI) and its amino-terminal derivate (rBPI21) were protective against lethal and sub-lethal challenges with Gram-negative bacteria and endotoxin [5]. Subsequent studies in humans, including studies in meningococcal sepsis, showed a significant protective effect of BPI, although it is not yet sufficient to be approved for clinical application. These studies strongly suggested that BPI can act in vivo to help resolve Gram-negative bacteria infections and endotoxin-induced inflammation [9]

In an open label, dose-escalation phase I/II trial, 26 pediatric patients with fulminant meningococcal sepsis were treated with rBPI21 administered 
intravenously. Only one of the patients (4\%) died, which favorably compared to a historical control group with $20 \%$ mortality (11 of 54 patients). In a subsequent phase III, randomized, placebo-controlled trial, 190 patients received $\mathrm{rBPI} 21$ and 203 received placebo. The beneficial effect of rBPI21 could be confirmed. The reduction in mortality did not reach statistical significance, probably because the study was underpowered by an inappropriate design not taking into account the high mortality of patients in the time between recruitment and drug administration [10].

BPI can induce apoptosis in human vascular endothelial cells in vitro and inhibit their migration in a wound assay [11]. The amino-terminal part of BPI (rBPI21) inhibited ischemia-induced or diabetesinduced neo-vascularization in the retina of mice, suggesting an antiangiogenetic effect of BPI. It is conceivable that BPI could impair the vascular access of GNB by inhibiting neo-angiogenesis in settings where chronic neutrophilic inflammation prevails, e.g., in inflammatory bowel diseases [12].

\section{References}

1. Grosfeld J. L., Othersen H. B. A tribute to Orvar Swenson on his 100th birthday. J. Pediatr. Surg. 2009;44(2):475. doi: 10.1016/j.jpedsurg.2009.01.004.

2. Warner B. W. Adaptation: paradigm for the gut and an academic career. J. Pediatr. Surg. 2013;48(1):20-26. doi: 10.1016/j.jpedsurg.2012.10.014.

3. Minaev S. V., Obozin V. S., Barnash G. M., Obedin A. N. The influence of enzymes on adhesive processes in the abdominal cavity. Eur. J. Pediatr. Surg. 2009;19(6):380383. doi: 10.1055/s-0029-1241847.

4. Minaev S. V., Tovkan E. A., Kachanov A. V., Isaeva A. V. An improvement of treatment newborns optimization of management of necrotizing enterocolitis in newborns. Medicinskii Vestnik Severnogo Kavkaza. - Medical News of North Caucasus. 2013;8(3):30-34. doi: 10.14300/ mnnc.2013.08007.

5. Zasloff M. Antimicrobial peptides of multicellular organisms. Nature. 2002;415(6870):389-395

6. Rowland K. J., Yao J., Wang L. et al. Up-regulation of hypoxia-inducible factor 1 alpha and hemodynamic responses following massive small bowel resection. J. Pediatr. Surg. 2013;48(6):1330-1339. doi: 10.1016/j.jpedsurg.2013.03.031.

\section{THE PROGNOSTIC VALUE OF BACTERICIDAL/ PERMEABILITY-INCREASING PROTEIN IN INFANTS WITH CONGENITAL PATHOLOGY OF THE GASTROINTESTINAL TRACT}

MINAEV S. V., ISAEVA A. V., TOVKAN E. A.,

GUDIEV CH. G., TIMOFEEV S. I., KACHANOV A. V., ROMANEEVA N.M.

The aim of this study was to investigate the influence of bactericidal/permeability-increasing protein (BPI) on the development of complications after abdominal surgery in infants

We investigated the intestinal hormone levels in the blood before and after surgery (1, 3, 7 and 14 postoperative days) in 24 infants with congenital intestinal obstruction anomaly and atresia. The children were divided into group $1(\mathrm{~N}=10)$, which included newborns with inflammatory complications after the surgery, and group $2(\mathrm{~N}=14)$, which included newborns without inflammatory complications. Twenty infants without operative treatment formed the control group. The level of BPI was determined by ELISA.
$\mathrm{BPI}$ is a pluripotent protein located in neutrophils and tissue that likely plays a pivotal role in host defense against microorganisms and endotoxin by means of its antibiotic and endotoxin-neutralizing and disposing functions. Further studies are needed to understand how BPI expression is controlled in different tissue cells. A better understanding of the regulation of $\mathrm{BPI}$ expression in epithelial and connective tissue settings may suggest novel approaches to increase the local antibacterial and anti-inflammatory properties and may be especially useful in newborns with congenital Gl anomalies.

\section{Conclusion}

1. The high level of BPI after surgery in infants with a congenital anomaly on the first postoperative day is a favorable prognostic sign regarding the disease outcome.

2. Initially, low levels of BPI in the serum of a child in conjunction with increased levels on the third day can serve as a marker of an unfavorable outcome, but further research is required in this area.

7. Schultz H., Weiss J. P. The bactericidal/permeability increasing protein (BPI) in infection and inflammatory disease. Clin. Chim. Acta. 2007;384(1-2):12-23

8. Minaev S. V., Kirgizov I. V., Obedin A. N. et al. Monitoring of inflammatory complications development in the newborns with congenital pathology of the gastrointestinal tract. Medicinskii Vestnik Severnogo Kavkaza. - Medical News of North Caucasus. 2013;8(2):30-33

9. Cahill R. A., Wang J. H., Redmond H. P. Enteric bacteria and their antigens may stimulate postoperative peritoneal adhesion formation. Surgery. 2007;141(3):403-410.

10. Giroir B. P., Scannon P. J., Levin M. Bactericidal/permeability-increasing protein - lessons learned from the phase III, randomized, clinical trial of rBPI21 for adjunctive treatment of children with severe meningococcemia. Crit. Care Med. 2001;29(7 Suppl):S130-135. Review.

11. Yamagata M., Rook S. L., Sassa Y. et al. Bactericidal/permeability-increasing protein's signaling pathways and its retinal trophic and anti-angiogenic effects. Faseb. J. 2006;20(12):2058-2067.

12. Wiesner J., Vilcinskas A. Antimicrobial peptides. The ancient arm of the human immune system. Virulence. 2010;1(5):440-464. doi: 10.4161/viru.1.5.12983.

\section{ПРОГНОСТИЧЕСКАЯ ЗНАЧИМОСТЬ}

БАКТЕРИЦИАНОГО БЕАКА, ПОВЫШАЮЩЕГО ПРОНИЦАЕМОСТЬ КАЕТОК У НОВОРОЖАЕННЫХ С ВРОЖАЕННОЙ ПАТОАОГИЕЙ ЖКТ

C. В. МИНАEB, A. B. ИСАEBA, E. A. TOBКАНЬ,

Ч. Г. ГУАИЕВ, С. И. ТИМОФЕЕВ, А. В. КАЧАНОВ,

H. M. POMAHEEBA

Цель: установить прогностическую значимость бактерицидного белка, повышающего проницаемость клеток (BPI), в развитии осложнений у новорожденных с хирургической патологией ЖКТ.

У 24 новорожденных с врожденной хирургической патологией ЖКТ перед операцией и на 1, 3, 7, 14 послеоперационные сутки исследовали уровень ВРІ в сыворотке крови. Были выделены 2 группы: группа № $1(n=10)$ - дети с послеоперационными осложнениями, группа № 2 $(n=14)$ - дети без осложнений.

Уровень BPI перед операцией в группе № 2 был выше, чем в группе № 1 (10.5 ng/ml (3,35$19,05)$ и $3,33 \mathrm{ng} / \mathrm{ml}(2,74-4,51), \mathrm{p}<0,05$, соот- 
The level of BPI before surgery in group 2 was significantly higher than that in group $1(10.5 \mathrm{ng} / \mathrm{ml}$ (3.35-19.05) and $3.33 \mathrm{ng} / \mathrm{ml}(2.74-4.51) \mathrm{p}<0.05$, respectively). In a group data comparison, BPI was significantly higher in group 1 , even on the third day after surgery $(2.915 \mathrm{ng} / \mathrm{ml}(1.37-55.5)$ and 15.75 $\mathrm{ng} / \mathrm{ml}(3.32-50.5) \mathrm{p}<0.05$, respectively). The data showed values of BPI in the group of patients with inflammatory complications that were higher than those in the main and comparison groups from the third postoperative day.

The increased BPI in the blood on the first postoperative day in newborns was a good prognostic sign. An initial low level BPI and the increased BPI in the blood on the third postoperative day in newborns was a poor prognostic sign and was evidence of development of inflammatory complications.

Key words: gastrointestinal tract, congenital anomaly, infants, bactericidal/permeability-increasing protein ветственно). При сравнении показателей ВРІ на третий день после операции отмечалось значительное $(p<0.05)$ его повышение в группе № $1(15,75$ ng/ml $(3,32-50,5))$ по сравнению с группой № $2(2,915 \mathrm{ng} / \mathrm{ml}(1,37-55,5))$. Установлено статистически достоверное $(p<0,05)$ увеличение уровня ВPI на 3-и сутки у пациентов с послеоперационными осложнениями.

Таким образом, высокий уровень ВPI у новорожденных с хирургической патологией ЖКТ в 1-е сутки благоприятный прогностический признак. Исходно низкий уровень ВРІ в сыворотке крови ребенка в сочетании с его нарастанием на 3-и сутки может служить маркером развития послеоперационных осложнений.

Ключевые слова: желудочно-кишечный тракт, врожденная аномалия, новорожденные, бактерицидный белок, повышающий проницаемость клеток

\title{
SLEEVE GASTRECTOMY FOR MORBID OBESITY - REGIONAL EXPERIENCE
}

\author{
Khatsiev B. B., Kuzminov A. N.
}

\section{Stavropol State Medical University, Russian Federation}

$\mathbf{M}$ orbid obesity is the actual issue for healthcare of developed countries. In Russia $51 \%$ of men and $58 \%$ of women are either overweight or obese[1]. Obesity is closely associated with type 2 diabetes mellitus, arterial hypertension and other diseases [2].

Meta-analysis of numerous randomized studies had shown that bariatric surgery can induce not only weight-loss, but also is more effective in management of type 2 diabetes mellitus than conservative treatment, including long-term period [3].

Sleeve gastrectomy is one of the most recent widely recognized bariatric procedures. While it is not completely clear whether it should be used as primary procedure, number of sleeve gastrectomies constantly increases [4]. In 2012 sleeve gastrectomy became the most common bariatric operation in Russia, shifting adjustable gastric banding to the second position [5].

Objective of research. This study summarizes result of three-year experience of sleeve gastrectomy at regional clinics of Stavropol kray. The results will contribute to the regional strategy of treatment

Khatsiev Bekhan, MD, PhD, deputy director of Clinic of endoscopic and minimally invasive surgery, Stavropol State Medical University; tel.: +79283211335; e-mail: bkhatsiev@yandex.ru

Kuzminov Alexander, MD, surgeon of Clinic of endoscopic and minimally invasive surgery, Stavropol State Medical University; tel.: +79283296633; e-mail: dr.kuzminov@gmail.com of morbid obesity and diabetes mellitus. This paper also aims to reveal information on bariatric surgery to regional surgeons, endocrinologists and general practitioners.

Material and Methods. We have been performing sleeve gastrectomies since December 2010. 116 operations have been made by the March 2014; 24 (21\%) patients are males, 92 (79\%) - females. Mean age of patients is $38.0 \pm 9.8$ years, minimal age -15 , maximal - 62. Average body mass index (BMI) is $46.5 \pm 7.3 \mathrm{~kg} / \mathrm{m}^{2}$, minimal BMl $-34.3 \mathrm{~kg} / \mathrm{m}^{2}$, maxi$\mathrm{mal}-72,7 \mathrm{~kg} / \mathrm{m}^{2}$. Maximal patient weight was $215 \mathrm{~kg}$.

Insulin resistance or glucose intolerance pre-operatively were find out in $16(13,8 \%)$ patients, $12(13,8 \%)$ patients suffered type 2 diabetes mellitus with oral therapy, $2(1.7 \%)$ more patients were on insulin treatment.

All procedures were carried put under general endotracheal anesthesia that was augmented in $12(10.3 \%)$ cases with peridural anesthesia. In $19 \%$ of cases other operations were performed simultaneously - 16 (13.8 \%) cholecystectomies, 4 (3.4\%) hernia repairs, $1(0.8 \%)$ ovarian cyst removal $n$ $1(0.8 \%)$ adhesiolysis.

2 operations were performed by laparotomy (due to multiple previous laparotomies), 1 operation commenced as laparoscopic, but was converted to hand-assisted with usage of minimally invasive system «Dextrus» due to enormous size of left hepatic 